Jpn. J. Oral Biol., $45: 1-7,2003$.

\title{
ORIGINAL
}

\section{Proteomic Analysis of Protein Expressed in Odontoblastic Differentiation of Bovine Dental Pulp Cells}

\author{
Shigeki Fujiwara, Kazushi Imai, Motoharu Seiki* and Kazuo Sanada \\ Department of Biochemistry, The Nippon Dental University, School of Dentistry at Tokyo \\ (Chief : Prof. Kazuo Sanada) \\ *Division of Cancer Cell Research, The Institute of Medical Science, The University of Tokyo \\ 1-9-20 Fujimi, Chiyoda-ku, Tokyo 102-8159, Japan \\ *4-6-1 Shirokanedai, Minato-ku, Tokyo 108-8639, Japan
}

(Received on July 31, 2002 ; Accepted on October 30, 2002)

\begin{abstract}
Key words : dental pulp/proteome analysis/odontoblast/differentiation/two-dimensional gel electrophoresis
\end{abstract}

\begin{abstract}
In response to injury, dental pulp cells differentiate into odontoblast-like cells to produce reparative dentin. To understand the mechanism of odontoblastic differentiation and to stimulate reparative dentin formation, we developed an in vitro culture system representing odontoblastic differentiation of bovine dental pulp cells and profiled the protein expression through proteomic analyses. Fractionation with which two-dimensional gel electrophoresis exhibited an analogous protein expression pattern between in vitro and in vivo pulp cells, but underlined differentially expressed proteins during the odontoblastic differentiation. Subsequent mass spectrometry and $\mathrm{NH}_{2}$-terminal amino acid sequence demonstrated degradation of vimentin into several species, up-regulation of connexin 43 and down-regulation of protein disulfide isomerase in the differentiating pulp cells and suggests the involvement of these proteins in odontoblastic differentiation.
\end{abstract}

抄録：歯髄細胞は，傷害に反応して象牙芽細胞様細胞に分化する。この細胞分化のメカ二ズムを理解するため に, in vitro でのウシ歯髄細胞の象牙芽細胞様分化モデルを作成し, プロテオーム解析によるタンパク質発現のプ ロファイリングを行った。二次元電気泳動で一次元目にアガロースゲル等電点電気泳動を行い, 質量分析と $\mathrm{N}$ 末 端領域のアミノ酸配列の解析によりスポットを同定した。培養歯髄細胞石扊化期における二次元マップを増殖期 のそれと比較すると, 8 スポットの増加と 3 スポットの減少が認められ, ビメンチンフラグメントあるいは未知の intermediate の出現と, コネキシン 43 の発現増加および PDI (protein disulfide isomerase) の減少が確認され た。これらの増減を示すタンパク質が象牙芽細胞様分化に関連している可能性がある。

\section{Introduction}

High resolution two-dimensional electrophoresis (2$\mathrm{DE}$ ), which fractionates proteins by $\mathrm{pI}$ and molecular weight, is the most reliable analytical method to determine protein composition in a given cell and tissue type. This experimental method can be used to monitor changes in gene activity via quantitative and qualitative analysis of the thousands of proteins that orchestrate various cellular functions. In combination with mass spectrometry analysis and the large protein database, the two-dimensional system is a powerful tool in proteome analysis ${ }^{1}$. The enamel organ and dental papilla constitute the dental germ. Dental papilla is packed into teeth as dental pulp cells and maintains an undifferentiated state ${ }^{2,3}$. Dental pulp cells differentiate into odontoblast-like cells and synthesize 
reparative dentin to counter damage by noxious stimuli such as caries and surgical procedures ${ }^{4}$. Many studies have focused on morphological changes of odontoblast-like cells and on factors which induce odontoblast-like cell differentiation ${ }^{3,5,6)}$. However, little information exists about the molecular mechanism of pulp cell differentiation into odontoblast-like cells. In the present study, we have investigated the protein expression profile of dental pulp cells to understand the molecular mechanisms of odontoblastic differentiation by proteomic analyses.

\section{Materials and Methods}

\section{Cell culture}

Dental pulp tissues were extracted from the incisor of adult Japanese black cows and treated with $0.2 \%$ trypsin and $0.2 \%$ collagenase to isolate dental pulp cells as previously described ${ }^{7}$. The isolated cells were cultured at a density of $4 \times 10^{4}$ cells $/ \mathrm{cm}^{2}$ in $1: 1$ mixture of Dulbecco's modified Eagle's medium and Ham's F12 medium (DME/F12 ; GIBCO BRL, Grand Island, NY, USA) supplemented with $10 \%$ calf serum (GIBCO BRL), $400 \mathrm{U} / \mathrm{m} l$ of penicillin and $100 \mu \mathrm{g} / \mathrm{m} l$ of streptomycin. The cultures were maintained in a $5 \% \mathrm{CO}_{2}$ incubator at $37^{\circ} \mathrm{C}$ and the medium was replaced every other day until day 28. Dental pulp cells at the day 7 or 21 were homogenized in an extraction buffer containing $6 \mathrm{M}$ urea, $1 \mathrm{M}$ thiourea, $0.5 \% 2-$ mercaptoethanol and protease inhibitors (Complete Mini EDTA-free, Boehringer Mannheim, Mannheim, Germany). The homogenate was centrifuged at $100,000 \times \mathrm{g}$ for $20 \mathrm{~min}$ at $4^{\circ} \mathrm{C}$, and the supernatants were subjected to $2-\mathrm{DE}$.

\section{2-DE}

First-dimensional agarose gel isoelectric focusing (IEF) was performed according to the method described $^{8}$. Homogenates of dental pulp tissues (400 $\mu \mathrm{g}$ of total protein) or cultured cells $(50 \mu \mathrm{g}$ of total protein) were electrophoresed on $1.1 \%$ agarose IEF gels containing 30\% ampholyte (Amersham Pharmacia Biotech, Uppsala, Sweden), 13.3\% D-solbitol, $6 \mathrm{M}$ urea and $1 \mathrm{M}$ thiourea. The first-dimensional IEF gels were then size fractionated by the second sodium dodecyl sulfate-polyacrylamide gel electrophoresis (SDS-PAGE) and stained with coomassie brilliant blue (CBB) and silver. To ensure reproducibility of the protein expression pattern, 2-DE was repeated with three separate samples.

\section{Mass spectrometry}

In gel digestion was performed by the method previously described ${ }^{9}$. Briefly, protein spots of interest were excised from SDS-PAGE gels and treated with dithiothreitol (DTT) and idoacetamide. After digestion by lysilendopeptidase (Takara, Osaka, Japan), the samples were applied to $\mathrm{C} 18$ reversedphase micro columns (Zip Tip, Millipore, Bedford, MA, USA) and analyzed by matrix-assisted laser desorption/ionization-time of flight-mass spectrometry (MALDI-TOF MS ; Voyager Elite MALDI mass spectrometer, PerSeptive Biosystems, Inc., Framingham, MA, USA). Searching in SWISS-PROT and NCBI databases using the MS-Fit program (http : // prospector.ucsf.edu/ucsfhtml 3.4/msfit.htm) were performed to identify amino acid composition of the samples. The criteria for positive identification of proteins were set as follows: (i) at least three matching peptide masses, (ii) $50 \mathrm{ppm}$ or better mass accuracy, and (iii) molecular weight and pI of identified proteins should match estimated values obtained from image analysis.

\section{Amino acid sequence analysis}

The $\mathrm{NH}_{2}$-terminal amino acid sequence was determined by the Procise 492 protein sequencing system (Applied Biosystems, Fostern city, CA, USA). For the sequence analyses of proteins of interest, products of the second-dimensional SDS-PAGE described above were transferred to polyvinylidene difluoride (PVDF) membrane ${ }^{10}$. The proteins on the membrane were located by staining with $0.1 \%$ Ponceau S. Protein spots of interest were then excised and sequenced.

\section{Histochemical staining}

Cultured pulp cells were fixed with $95 \%$ methanol for $20 \mathrm{~min}$ and stained with 1\% Alizarin red S (Sigma, St. Louis, MO, USA) for 5 min as described by Dahl ${ }^{11}$. For calcein blue staining, cells were incubated with 


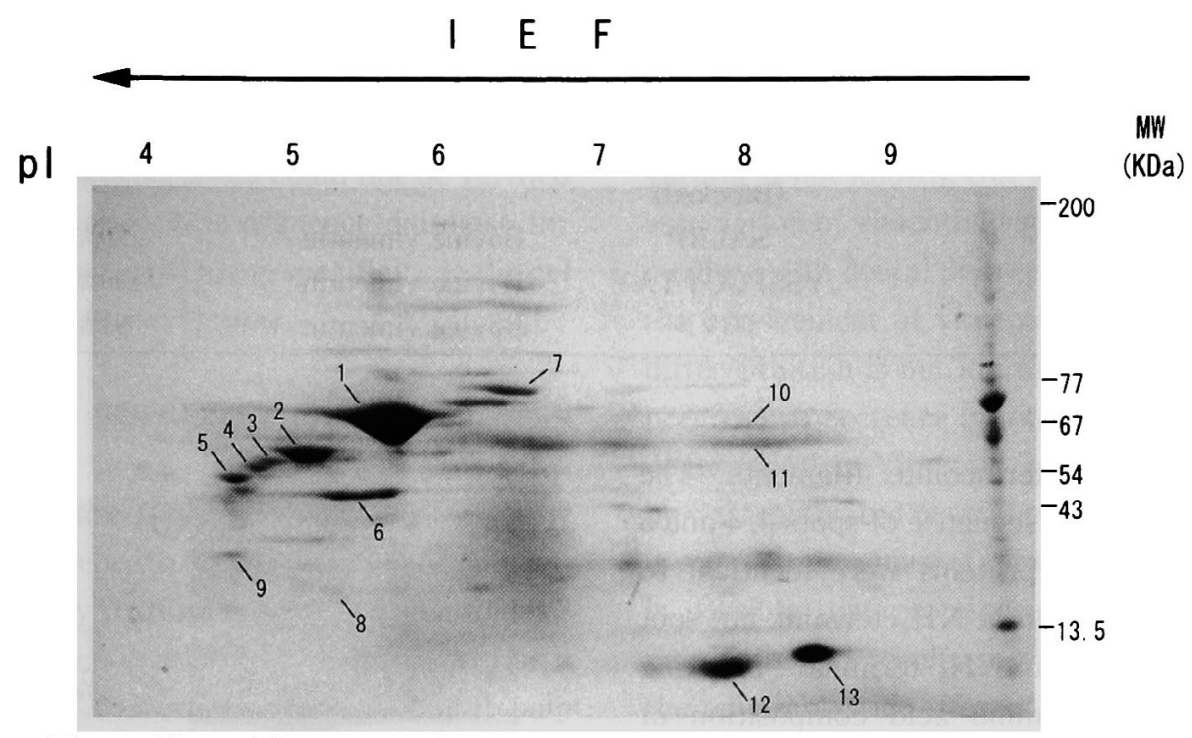

Fig. 1 The 2-DE pattern of protein extracted from dental pulp tissue. Tissue homogenates were separated by $\mathrm{pI}$ (IEF) and size fractionated by molecular weights (SDS-PAGE). The size marker is shown on the right side of the gel. Spots 1 albumin, spots $2-5$ vimentin intermediate filaments, spot $6 \alpha^{-}$ actin, spot 7 transferrin, spot 8 apolipoprotein A-I, spot 12 and 13 hemoglobin $\beta$ chain and hemoglobin $\alpha$ chain.

$3.1 \times 10^{-5} \mathrm{M}$ of calcein blue (Dojin Chemical, Kumamoto, Japan) in DME/F 12 medium for $60 \mathrm{~min}$ at $37^{\circ} \mathrm{C}$ followed by fixation with $3.7 \%$ neutral buffered formalin for $60 \mathrm{~min}$ at room temperature. Confocal laser scanning microscopy (TCS-SP, Leica, Wetzal, Germany) was employed to examine mineralized extracellular matrix.

\section{Results}

\section{The differentiation of dental pulp cells into odontoblast-like cells}

The pulp cell differentiation observed was similar to the cells described previously by Kasugai, et al. ${ }^{12)}$ and Nakashima ${ }^{7)}$ in vitro, confirming our early work $^{13)}$. During the initial period of dental pulp cell culture, only a small fraction of cells remained attached to culture dishes. Most of the adherent cells appeared fibroblastic with few short cellular processes. We histologically classified the pulp cell differentiation into three stages. Fibroblastic cells with predominant growth activity up to day 12 were defined as the proliferating stage. After day 7, the fibroblastic cells gradually extended cellular volume. The population doubling time was about 3.4 days. At the differentiating stage from day 12 to 18 , pulp cells formed multilayered nodules that were surrounded by tall columnar cells. The mineralizing stage after day 18 was characterized by calcified matrices within the nodules and by differentiation of the columnar cells into odontoblast-like cells with a long cytoplasmic extension.

\section{Protein expression in the dental pulp tissues}

The two-dimensional pattern of protein expressed in dental pulp tissues is shown in Fig. 1. The most intensely stained protein spots were observed in the acidic area (pI 4-7) in addition to two low molecular weight spots in the basic area (pI 7-9). Complete match of the amino acid composition in the mass spectrometric analysis identified spots 1, 6, 7, 8, 12 and 13 as bovine albumin, $\alpha$-actin, transferrin, apolipoprotein A-I, hemoglobin $\beta$ chain and hemoglobin $\alpha$ chain, respectively. Partially matched amino acid composition (76-92\%), molecular weight and $\mathrm{pI}$ highly suggested that spots $2-5$ were degradation 
Table 1 Amino acid sequence of proteins expressed in dental pulp tissue

\begin{tabular}{ccccc}
\hline Spot No. & Start residue & N-terminal sequence & Homologus protein & MS peptide matching \\
\hline 1 & 25 & DYHKS & Bovine albumin & $100 \%$ \\
2 & - & (Blocked) & - & - \\
3 & 41 & SALRP & Bovine vimentin & $76 \%$ \\
4 & 53 & YSSPGGVYAY & Bovine vimentin & $100 \%$ \\
5 & 71 & SGVP & Bovine vimentin & $91 \%$ \\
\hline
\end{tabular}

products of vimentin intermediate filaments. The $\mathrm{NH}_{2}$-terminal amino acid sequence of spots 3,4 and 5 demonstrated that these proteins were identical to bovine vimentin with different $\mathrm{NH}_{2}$-termini, but spot 2 was undetectable on $\mathrm{NH}_{2}$-terminal blocking (Table 1). Theoretical amino acid composition of vimentin species starts from $\mathrm{Ser}^{41}, \mathrm{Tyr}^{53}$ and $\mathrm{Ser}^{71}$ were, in fact, identical with the mass spectrometry data of spots 3 (peptide matching $76 \%$, sequence coverage $35 \%$ ) , 4 (peptide matching $100 \%$, sequence coverage $33 \%$ ) and 5 (peptide matching $91 \%$, sequence coverage $38 \%$ ), respectively. The amino acid sequence identified spot 1 as bovine albumin, but did not identify spots $6-8$ by amino acid blocking. Other protein spots on 2-DE gels (spot 9 in the acidic area and spots 10 and 11 in the basic area) could not be verified due to an insufficient amino acid sequence database for bovine proteins or to lack of enzyme specificity used in the gel digestion, and could not be identified through the $\mathrm{NH}_{2}$-terminal sequence because of amino acid blocking.

\section{Identification of protein expression in cul- tured dental pulp cells}

The protein expression pattern of the cultured pulp cells was comparable with that of pulp tissue except for albumin and hemoglobin observed in the tissue sample. Profiling of protein expression in cells performed at different time points (days 7 and 28) on 2-DE gels demonstrated unique proteins with cellular differentiation (Fig. 2). On day 28, odontoblast-like cells increased the intensity of eight proteins ( $\operatorname{spots} c, e-j$, and $p$ ) but decreased that of three proteins (spots a, $\mathrm{k}$ and 1) compared with cells on day 7 . Other protein spots (b, $d, m-o$ and $q$ ) were indistinguishable between these time points. Protein mobility on the gel

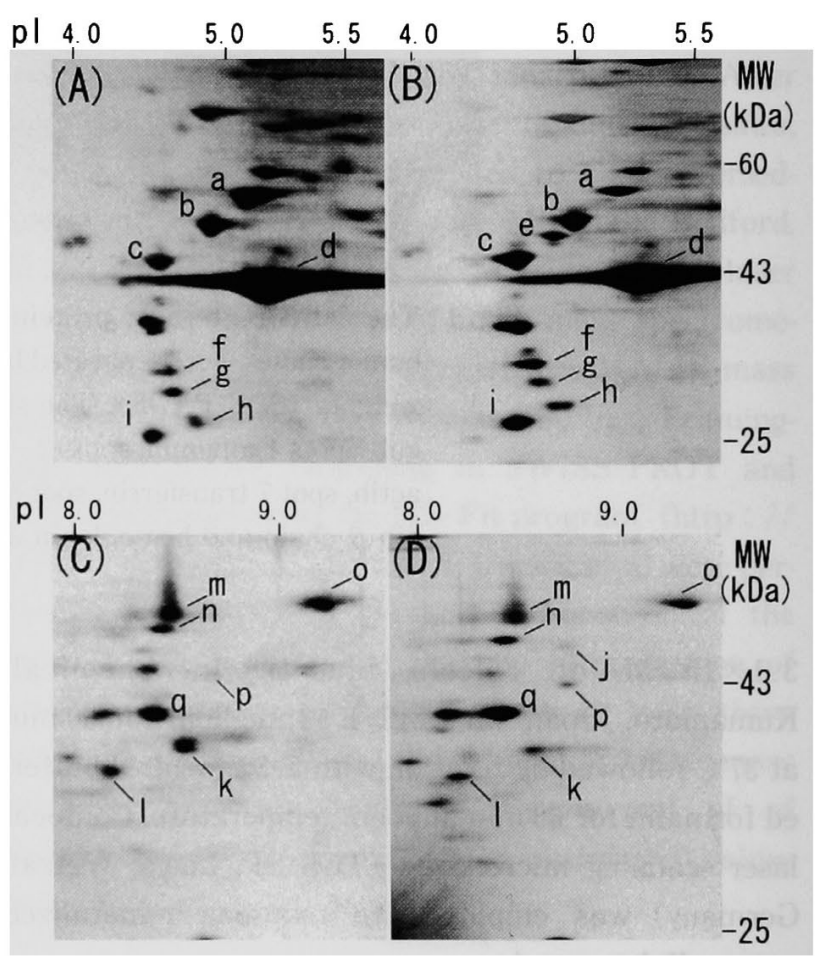

Fig. 2 Protein profiles expressed in dental pulp cells. Samples of cultured dental pulp cells on day 7 (A and $\mathrm{C}$ ) or day 28 (B and D) were applied to 2-DE analysis. Protein running in the acidic area ( $\mathrm{A}$ and B) exhibited increased staining intensity of spots $c$ and $\mathrm{e}-\mathrm{i}$, but a decrease of spot a on the day 28 sample (B). In the basic area (C and D), spots $j$ and $\mathrm{p}$ were increased in contrast to spots $\mathrm{k}$ and $\mathrm{l}$ on the day 28 sample (D).

predicted spots b (peptide matching $56 \%$, Sequence coverage $41 \%$ ), c (peptide matching $56 \%$, Sequence coverage $46 \%$ ) and e (peptide matching $56 \%$, Sequence coverage $36 \%$ ) as vimentin and spot $d$ as $\boldsymbol{\alpha}$-actin. Thereafter, mass spectrometric analyses confirmed our prediction. The peptide mass fingerprint of spots $a$ and $\mathrm{j}$ by the MS-Fit search algorithm most closely 
matched protein disulfide isomerase (PDI ; peptides matching $4 / 8$, sequence coverage $15 \%$ ) and connexin 43 (peptides matching $3 / 12$, sequence coverage $13 \%$ ), respectively. Other protein spots could not be verified due to insufficient amino acid sequence database for bovine proteins or lack of enzyme specificity in the gel digestion as well as in the tissues.

\section{Discussion}

Dental pulp cells are responsive to injury and grow reparative dentine beneath the wound surface, indicating their adaptability to differentiate into odontoblastlike cells and produce dentin matrices. This will be a great advantage in conserving residual dental pulp clinically, provided we are able to differentiate pulp cells to odontoblasts and/or stimulate dentin formation by existing odontoblasts. Although various agents have been studied for a long time to induce reparative dentin ${ }^{14-17)}$, effective treatment has not yet been established. Understanding the molecular mechanism(s) that regulate odontoblastic differentiation could provide clues to develop biological dental capping agents that stimulate formation of reparative dentine. In the present study, we developed an in vitro culture system of dental pulp cells representing odontoblastic differentiation and calcified matrix deposition. The morphological cellular differentiation in dishes confirmed previous studies ${ }^{7,12}$. To appreciate the molecular expression profile, we have fractionated protein expressed in pulp tissues and cultured cells. Analyses of the profile by $2-\mathrm{DE}$, mass spectrometry and $\mathrm{NH}_{2}{ }^{-}$ terminal amino acid sequence showed an almost identical pattern of protein expression between the tissues and cultures except for albumin and hemoglobin. Although albumin and hemoglobin may have resulted from serum contamination, confirmation of the profile indicates that other proteins are derived from dental pulp cells.

Proteome analysis in this study disclosed the differential expression and posttranslational degradation of protein during pulp cell differentiation. Vimentin and $\alpha$-actin are major cytoskeletal components in dental pulp cells and odontoblasts ${ }^{18-21}$. In our study, dental pulp tissue and cells revealed the spots of vimentin degradation products. The consecutive pattern of electromobility of vimentin species indicates an acidic shift with their degradation, because any splicing variant is not known. Our study also demonstrated an association of vimentin degradation or unknown intermediate with dental pulp cell differentiation. Although the involvement of vimentin degradation in pulp cell differentiation is not known, Dahl, et al. ${ }^{22)}$ reported a progressive decrease in intact vimentin during neural differentiation. Vimentin is susceptible to degradation by $\mathrm{Ca}^{2+}$-activated neutral proteinase (calpain), which is expressed in many types of tissues and cells ${ }^{23,24}$. It is possible that proteinase is also present in dental pulp cells and results in vimentin proteolysis during the odontoblastic differentiation of the cells. Further studies will be required to address the role of vimentin degradation in pulp cell differentiation.

PDI was originally determined to catalyze the metabolism of protein disulfide bonds ${ }^{25}$. Green and Brophy $^{26)}$ reported that PDI activity is elevated in proliferating neuroblastoma cells but waned by formation of cell-cell adhesion. Predominant expression of PDI in proliferating pulp cells suggests a role for this protein in cell proliferation and involvement in the early events in odontoblast-like differentiation.

The connexin gene family is a major constitutent of the gap junction promoting growth and differentiation in various cell-types ${ }^{27)}$. Fried, et al. ${ }^{28)}$ reported that connexin 43 expression is up-regulated when dental pulp cells are exposed to mechanical injury. The physiological significance and mechanism of connexin 43 up-regulation are not yet clear. However, a recent study indicates a positive role for connexin 43 in differentiation and proliferation of preodontoblasts ${ }^{29}$. Up-regulation of connexin 43 expression in differentiating pulp cells highlights the possibility of gap junctional regulation in odontoblastic differentiation.

In the present study, we demonstrated vimentin degradation, PDI down-regulation and connexin 43 up-regulation in the odontoblastic differentiation of dental pulp cells through proteomic analyses. Further avenues of research are expected to define the link between these events and pulp cell differentiation, and develop biological dental capping agents that induce reparative dentin. 


\section{Acknowledgements}

We are grateful to Dr. M. Oh-ishi (Department of Physics, School of Science, Kitasato University, Kanagawa, Japan) for generous advice and to Dr. J. D'Armiento (Columbia University P\&S, NY, USA) for critical reading of the manuscript.

\section{References}

1) O'Farrell, H. P. : High evolutional two-dimensional electrophoresis of protein. J. Biol. Chem. 250 : 4007-4021, 1975.

2) Yamamura, T. : Differentiation of pulpal cells and inductive influences of various matrices with reference to pulpal wound healing. J. Dent. Res. 64: $530-540,1985$.

3) Fitzgerald, M., Chiego, D. J. and Heys, D. R. : Autoradiographic analysis of odontoblast replacement following pulp exposure in primate teeth. Arch. Oral Biol. 35: 707-715, 1990.

4) Cox, F. C. : Histology of pulp organ. In : Oral development and histology. (edited by Avery, K. J.), pp. 175-177, Williams and Wilkins, Baltimore, MD., 1986.

5) Nakashima, M., Nagasawa, H., Yamada, Y. and Reddi, H. A. : Regulatory role of transforming growth factor- $\beta$, bone morphogenic protein-2, and protein-4 on gene expression of extracellular matrix proteins and differentiation of dental pulp cells. Dev. Biol. 162 : 18-28, 1994.

6) Toyono, T., Nakashima, M., Kuhara, S. and Akamine, A. : Temporal changes in expression of transforming growth factor- $\beta$ superfamily members and their receptors during bovine preodontoblast differentiation in vitro. Arch. Oral Biol. 42 : 481-488, 1997.

7) Nakashima, M. : Establishment of primary cultures of pulp cells from bovine permanent incisors. Arch. Oral Biol. 36 : 655-663, 1991.

8) Oh-ishi, M., Satoh, M. and Maeda, T. : Preparative two-dimensional gel electrophoresis with agarose gels in the first dimension for high molecular mass proteins. Electrophoresis $21: 1653-1669,2000$.

9) Shevechenko, A., Wilm, M. Vorm, O. and Mann, M. : Mass spectrometric sequencing of proteins from silver-stained polyacrylamide gels. Anal. Chem. 68: 850-858, 1996.
10) Hirano, H. and Watanabe, T. : Microsequencing of proteins electrotranferred onto immobilizing matrices from polyacrylamide gel electrophoresis: Application to an in soluble protein. Electrophoresis $11: 573-580,1990$.

11) Dahl, L. K. : A simple and sensitive histochemical method for calcium. Proc. Soc. Exp. Biol. Med. 80 : 474-479, 1952.

12) Kasugai, S., Adachi, M. and Ogura, H. : Establishment and characterization of a clonal cell line (RPC-C2A). Arch. Oral Biol. 33 : 887-891, 1988.

13) Fujiwara, S., Imai, K. and Sanada, K. : Gene expression of bovine dental pulp cells in vitro during odonto-blastlike cell differentiation. Jpn. J. Oral Biol. 43 : 402-409, 2001.

14) Nyborg, H. : Healing processes in the pulp on capping. Acta Odontol. Scand. 13:9-13, 1955.

15) Nyborg, H.: Capping of the pulp: the processes involved and their outcome. Odontol. Tidskr. 66 : 296-364, 1958.

16) Haskell, E. W., Stanley, H. R., Chellemi, J. and Stringfellow, H. : Direct pulp capping treatment : a long-term follow-up. J. Am. Dent. Assoc. 97 : 607-612, 1978.

17) Fitzgerald, M. and Heys, R. J. : A clinical and histological evaluation of conservative pulpal therapy in human teeth. Oper. Dent. 16:101-112, 1991.

18) Alliot-Licht, B., Hurtrel, D. and Gregoire, M. : Characterization of $\alpha$-smooth muscle actin positive cells in mineralized human dental pulp cultures. Arch. Oral Biol. 46:221-228, 2001.

19) Lombardi, T., Samson, J., Muhlhaser, J., FioreDonno, G., Maggiano, N. and Castellucci, M. : Expression of intermediate filaments and actins in human dental pulp and embryonic dental papilla. Anat. Rec. 234 : 587-592, 1992.

20) Pelissier, A., Ouhayoun, P. J., Sawaf, H. M. and Forest, N. : Evolution of cytokeratin expression in developing human tooth germ. J. Biol. Buccale. 18 : 99-108, 1990.

21) Sigal, J. M., Aubin, E. J. and Cate, T. A. R. : An immunocytochemical study of the human odontoblast process using antibodies against tubulin, actin, and vimentin. J. Dent. Res. 64: 1348-1355, 1985.

22) Dahl, D., Strocchi, P. and Bignami, A. : Vimentin in the central nervous system, A study of the mesenchymal-type intermediate filament-protein in Wallerian degeneration and in postnatal rat development by two-dimensional gel electrophoresis. 
Differentiation 22: 185-190, 1982.

23) Nelson, J. W. and Traub, P. : Properties of a $\mathrm{Ca}^{2+}$ activated protease specific for the intermediatesized filament protein vimentin in Ehrlich-ascitestumour cells. Eur. J. Biochem. $116: 51-57,1981$.

24) Nelson, W. J. and Traub, P. : Intermediate $(10 \mathrm{~nm})$ filament proteins and the $\mathrm{Ca}^{2+}$-activated proteinase specific for vimentin and desmin in the cells from fish to man : an example of evolutionary conservation. J. Cell Sci. $57: 25-49,1982$.

25) Noiva, R. and Lennarz, W. J. : Protein disulfide isomerase. A multifunctional protein resident in the lumen of the endoplasmic reticulum. J. Biol. Chem. 267 : 3553-3556, 1992.

26) Green, J. J. and Brophy, I. C. : Induction of protein disulfide isomerase during proliferation arrest and differentiation of SH5Y neuroblastoma cells. Cell.
Mol. Biol. 41 : 473-480, 1995.

27) Bruzzone, R., White, T. W. and Paul, D. L. : Connections with connexins: The molecular basis of direct intercellular signaling. Eur. J. Biochem. 238 : 1-27, 1996.

28) Fried, K., Mitsiadis, A. T., Guerrier, A., Haegerstrand, A. and Meister, B. : Combinatorial expression patterns of the connexins 26,32 and 43 during development, homeostasis and regeneration of rat teeth. Int. J. Dev. Biol. 40 : 985-995, 1996.

29) Gramsch, B., Gabriel, D. H., Wiemann, M., Grümmer, R., Winterhager, E., Bringmann, D. and Schirrmacher, K. : Enhancement of connexin 43 expression increases proliferation and differentiation of an osteoblast-like cell line. Exp. Cell Res. 264: 397-407, 2001. 